\title{
STUDI EVALUASI EFEKTIVITAS PENGELOLAAN PERPUSTAKAAN STMIK STIKOM INDONESIA
}

\author{
I M Dedy Setiawan',*, I N Agus Suryanatha²
}

1 STMIK STIKOM Indonesia (STIKI) DENPASAR

2 STMIK STIKOM Indonesia (STIKI) DENPASAR

\begin{abstract}
Abstrak
This study aims to describe and analyze the effectiveness of library management in the STMIK STIKOM Indonesia library in terms of Context, Input, Process, and Product, as well as the constraints faced during program implementation and which may occur if the program is continued. This research will be done in STMIK STIKOM Indonesia Library by involving STIKI chairman, librarian, lecturer, and student. The determination of respondents was stratified random sampling. This research uses ex post facto research approach, and the data obtained will be analyzed descriptivelyquantitative. Methods of data collection using questionnaires, documentation, and interviews. Analyze the data using the $\mathrm{T}$ score formula which is subsequently converted into the Glickmann Quadrant. The results showed that the component context, input, process, and product produce positive category $(++++)$ that enter into quadrant I (very effective). In the context, input, and process components there are less effective constraints on the respondents of librarians and librarians, while in the product components are not found constraints.
\end{abstract}

\author{
Keywords: \\ Evaluation, \\ Effectiveness, Library \\ management
}

\section{PENDAHULUAN}

Pendidikan memegang peranan penting dalam proses peningkatan sumber daya manusia (SDM). Peningkatan kualitas pendidikan merupakan suatu proses terintegrasi dalam peningkatan SDM itu sendiri. Oleh karena itu peningkatan SDM merupakan kenyataan yang harus dilakukan secara terencana, terarah, intensif, efektif, dan efisien dalam menghadapi persaingan memasuki era globalisasi yang sangat kompetitif. Dalam menempuh pendidikan manusia tidak pernah terlepas dari proses belajar. Belajar merupakan suatu aktivitas mental, yang berlangsung dalam interaksi aktif dengan lingkungan, yang menghasilkan sejumlah perubahan dalam pengetahuan, pemahaman, keterampilan dan nilai sikap.

Kehidupan dunia pendidikan tidak terlepas dari perkembangan ilmu pengetahuan dan teknologi (IPTEK), artinya dalam perkembangan IPTEK harus diikuti dengan perkembangan pendidikan. Sebab sampai saat ini lembaga-lembaga pendidikan seperti perguruan tinggi merupakan wadah dalam mendidik masyarakat untuk mampu mengenal dan menciptakan IPTEK tersebut. Pendidikan juga memegang peran yang sangat penting dalam meningkatkan sumber daya manusia. Hal itu menjadi sebuah tantangan bagi lembaga pendidikan untuk melakukan perubahan-perubahan seiring dengan tuntutan terhadap dunia pendidikan yang semakin berkembang dengan selalu memberikan pelayanan yang terbaik.

Dalam proses pendidikan, manusia akan menempuh berbagai jenjang pendidikan, salah satu jenjang tertinggi yang ditempuh adalah perguruan tinggi. Perguruan Tinggi pada masa yang akan datang dihadapkan pada tantangan perubahan yang sangat cepat dan variatif sebagai dampak kemajuan IPTEK serta proses globalisasi. Pendidikan adalah salah satu bentuk perwujudan kebudayaan manusia yang dinamis dan sarat perkembangan. Hal tersebut terjadi sejalan dengan perubahan dan peningkatan pendidikan. Perubahan dalam arti perbaikan pendidikan telah lama diupayakan di Indonesia. Kegiatan memajukan pendidikan di Indonesia telah dilakukan melalui peningkatan kualitas pendidikan yang diwujudkan dalam undang-undang nomor 20 Tahun 2003 tentang Sistem Pendidikan Nasional (SISDIKNAS). Pasal 11 telah menyebutkan bahwa pemerintah dan pemerintah daerah wajib memberikan layanan dan kemudahan, serta menjamin terselenggaranya pendidikan yang bermutu bagi setiap warga negara tanpa diskriminasi, salah satunya adalah jenjang pendidikan tinggi.

Untuk mencapai tujuan yang telah digariskan dalam Tri Dharma Perguruan Tinggi yaitu peningkatan mutu pendidikan dan pengajaran, penelitian dan pengabdian kepada masyarakat. Perguruan

* Corresponding author.

E-mail Addresses: - 
Tinggi harus berusaha semaksimal mungkin untuk mewujudkan lingkungan kampus yang mendukung ke arah pencapaian tersebut. Perguruan tinggi merupakan tempat untuk membentuk cendikiawan yang memiliki sejumlah pengetahuan yang luas. Sarjana-sarjana yang berguna bagi masyarakat, bangsa, dan negara. Hal ini dapat dilakukan dengan cara belajar. Dengan belajar manusia melakukan perubahanperubahan tingkah laku sebagai hasil pengetahuannya berinteraksi dengan lingkungannya sehingga tingkah laku berkembang.

Dalam proses belajar di perguruan tinggi, mahasiswa juga mengalami berbagai hambatan. Hambatan tersebut dapat berasal dari diri mahasiswa itu sendiri dan juga dari lingkungan sekitar mahasiswa. Faktor penghambat dari dalam diri manusia atau faktor internal meliputi faktor fisiologis dan biologis serta faktor psikologis, sedangkan faktor dari luar diri manusia atau faktor eksternal dapat digolongkan menjadi faktor lingkungan sosial dan non-sosial.

Faktor eksternal seperti keadaan lingkungan kampus sangat berpengaruh dalam mendukung proses pembelajaran. Dalam proses belajar mahasiswa memerlukan tempat yang nyaman, selain itu sarana dan prasarana yang mendukung dalam proses pencarian sumber bahan ajar yang relevan sangatlah diperlukan mahasiswa dalam menunjang proses belajar. Selain memanfaatkan teknologi dalam memperoleh informasi dan ilmupengetahuan mahasiswa juga perlu memperdalam pengetahuannya melalui membaca sumber-sumber ilmu pengetahuan melalui buku-buku bacaan. Salah satu tempat yang dapat dimanfaatkan mahasiswa dalam memperoleh informasi dan ilmu pengetahuan melalui buku-buku bacaan adalah perpustakaan.

Pemanfaatan perpustakaan oleh mahasiswa sangat erat kaitannya dengan proses perkuliahan yang diselenggarakan oleh perguruan tinggi. Hal ini karena pola pengajaran yang disebut sebagai keterbukaan informasi untuk memperoleh sebanyak-sebanyaknya ilmu pengetahuan hanya akan terlaksana jika mahasiswa dapat memanfaatkan perpustakaan. Noerhayati (dalam Prayantini, 2014: 2) menyatakan bahwa dosen hanya memberikan kuliah-kuliah secara garis besarnya saja, sedangkan untuk detailnya mahasiswa diminta mengembangkan melalui buku-buku, termasuk buku-buku yang ada di perpustakaan, kemudian mata kuliah itu diseminarkan atau didiskusikan. Sistem seperti ini menjadikan mahasiswa harus memanfaatkan perpustakaan untuk mencari dan menelaah buku-buku yang ada di perpustakaan dalam proses balajarnya. Namun ada juga di kalangan mahasiswa yang tidak memanfaatkan perpustakaan dalam proses balajarnya karena merasa bahwa bahan kuliah yang diberikan oleh dosen sudah mencukupi.

Perpustakaan merupakan sumber belajar penting yang ada di lingkungan kampus dan harus dimanfaatkan sepenuhnya oleh mahasiswa. STMIK STIKOM Indonesia memiliki perpustakaan yang dikelola oleh pihak lembaga kampus serta berbagai fasilitas dan layanan yang tersedia di perpustakaan termasuk bahan literatur, jurnal, majalah, dan hasil-hasil penelitian.

Undang-undang nomor 43 tahun 2007 tentang perpustakaan telah menyebutkan bahwa setiap perguruan tinggi menyelenggarakan perpustakaan yang memenuhi standar nasional perpustakaan dengan memperhatikan Standar Nasional Pendidikan. Berkaitan dengan hal ini, sebagai perguruan tinggi swasta yang berdiri sejak tahun 2008, tentunya STMIK STIKOM Indonesia selain berinovasi, juga senantiasa membenahi diri menuju arah yang lebih baik dengan mengamanatkan undang-undang yang dimaksud serta tujuan yang diamanatkan dalam Tri Dharma Perguruan Tinggi untuk mewujudkan tujuan pendidikan nasional.

Dengan adanya kenyataan seperti ini maka evaluasi terhadap pengelolaan perpustakaan STMIK STIKOM Indonesia perlu dilakukan. Sebab bagaimanapun juga, dengan melihat betapa pentingnya peranan perpustakaan bagi penyelenggaraan pendidikan yaitu sebagai sumber belajar dan sumber informasi untuk menunjang kegiatan belajar mengajar dan kurikulum, maka pengelolaan perpustakaan STMIK STIKOM Indonesia sebagai perpustakaan perguruan tinggi perlu dikembangkan dan diefektifkan, namun harus disertai dengan pemeliharaan terhadap bahan koleksi perpustakaan agar berfungsi dengan baik.

Evaluasi dilakukan untuk mengetahui tingkat efektivitas program yang sedang ataupun sudah berjalan, sehingga melalui evaluasi dapat dilihat hambatan-hambatan dalam program untuk dicarikan solusinya (Arikunto, 2012). Hal ini tentu saja sangat berguna dalam pengambilan keputusan oleh pemegang kebijakan program, dalam hal ini adalah stakeholder di lingkungan STMIK STIKOM Indonesia terkait dengan program pengelolaan perpustakaan.

Stufflebeam (dalam Marhaeni, 2012) mengemukakan model evaluasi CIPP (Context, Input, Process, Product) yang merupakan alat evaluasi yang dapat menjelaskan serta menyediakan informasi yang berguna bagi sebuah keputusan yang terbaik. Variabel context berkaitan dengan lingkungan/latar yang meliputi kemajuan IPTEKS, nilai dan harapan masyarakat, dukungan pemerintah dan masyarakat, kebijakan pemerintah, landasan yuridis, tuntutan ekonomi, tuntutan globalisasi, tuntutan pengembangan diri, serta peluang output untuk sukses. Variabel input berkaitan dengan segala sesuatu yang diperlukan untuk berlangsungnya proses pendidikan yang meliputi kurikulum, ketenagaan, dana, sarana dan 
prasarana, regulasi sekolah, organisasi sekolah administrasi sekolah, dan budaya sekolah. Variabel process berkaitan dengan pertanyaan seberapa jauh kegiatan yang dilaksanakan sudah terlaksanan sesuai dengan rencana. Sedangkan Variabel product diarahkan pada hal-hal yang menunjukkan perubahan yang terjadi pada masukan mentah.

Ada beberapa penelitian yang dilakukan terkait dengan penelitian ini diantaranya penelitian oleh Oka Dharma (2013) tentang Efektifitas Program Pengelolaan Perpustakaan di UPT Perpustakaan STMIK STIKOM Indonesia dengan Model CIPP. Hasil penelitian menunjukkan bahwa efektivitas pengelolaan perpustakaan di UPT Perpustakaan STMIK STIKOM Indonesia dari segi variabel konteks diperoleh 55,17\% kategori positif; dari segi variabel masukan (input) diperoleh 55,17\% kategori positif, sedangkan hasil analisis variabel proses menunjukkan bahwa 51,72\% merupakan kategori positif. Sementara itu, dilihat dari segi variabel hasil (Kepuasan Pustakawan + Kepuasan Pemustaka) ditemukan bahwa 58,91\% adalah kategori positif. Hasil analisis data dari keempat variabel, yaitu konteks, input, proses, dan produk (kepuasan pustakawan dan kepuasan pemustaka) menunjukkan bahwa semua data berkatagori positif $(+)$. Sesuai dengan kuadran Glickman, formula CIPP $(++++)$ berada pada kuadran I. Dengan demikian berarti bahwa pelaksanaan pengelolaan program perpustakaan di UPT Perpustakaan STMIK STIKOM Indonesia berjalan dengan efektif.

Berdasarkan pentingnya program dan harapan yang ingin dicapai, serta dikaitkan dengan latar belakang permasalahan, landasan teori, dan kajian pustaka yang berkaitan dengan permasalahan dimaksud, maka dapat dirumuskan kerangka berpikir yang disajikan dalam bentuk fungsi dengan formula sebagai berikut.

$\mathrm{K}=\mathrm{f}(\mathrm{C}+\mathrm{I}+\mathrm{P}+\mathrm{P})(1)$

(Mastaadhi, 2010: 79)

Dengan memperhatikan formula tersebut dapat dijelaskan bahwa pengelolaan perpustakaan adalah fungsi dari konteks, masukan, dan proses. Konteks yang dimaksud adalah deskripsi dari visi misi perguruan tinggi, keberadaan sumber belajar, kurikulum, sarana pendukung kegiatan pendidikan, landasan hukum/kebijakan pendidikan yang berlaku, dan daya dukung masyarakat terhadap program. Masukan difokuskan pada daya dukung yang dibutuhkan untuk melaksanakan proses dalam program pengelolaan yang meliputi pengadaan ruangan perpustakaan yang memadai, perabot perpustakaan, koleksi bahan pustaka, dan sumber dana. Proses adalah keterlaksanaan program yang menyangkut halhal yang berhubungan dengan keterlaksanaan program perpustakaan kampus, proses pengadaan koleksi, proses tugas kepegawaian, dan proses administrasi. Hasil berkaitan dengan perubahan yang terjadi pada masukan mentah setelah melewati proses yang menyangkut terwujudnya perpustakaan STIKI menjadi pusat kegiatan pembelajaran, terjadinya transfer atau alih informasi dari berbagai sumber di perpustakaan, kepuasan pengunjung terhadap kualitas layanan yang diberikan, dan terjadi peningkatan refleksi kunjungan.

Memperhatikan uraian di atas, maka tujuan umum dari penelitian ini adalah untuk mengetahui efektivitas pengelolaan perpustakaan STMIK STIKOM Indonesia ditinjau dari komponen konteks, input, proses, dan produk.

\section{METODE PENELITIAN}

Jenis penelitian yang dilakukan adalah penelitian evaluasi. Penelitian dilaksanakan di perpustakaan STMIK STIKOM Indonesia (STIKI) Denpasar, dengan banyak populasi 2.434 orang yang terdiri dari kepala perpustakaan, pustakawan, dosen, dan mahasiswa.

Sampel penelitian diperoleh dengan menggunakan teknik Disproportionate Stratified Random Sampling. Hal ini disebabkan karena populasi berstrata tetapi kurang proporsional. Implikasinya, Kepala perpustakaan dan pustakawan diambil semuanya sebagai sampel, sedangkan penentuan sampel untuk yang lainnya menggunakan rumus ukuran sampel berdasarkan populasi yang diketahui. Berdasarkan ketentuan pengambilan sampel oleh Candiasa (2011a) maka dosen diambil sebanyak 20 orang, sedangkan mahasiswa diambil sebanyak 100 orang. Sehingga total sampel sebanyak 123 orang.

Objek penelitian ini adalah efektivitas pengelolaan Perpustakaan STMIK STIKOM Indonesia dilihat dari empat komponen utama yaitu 1) Komponen Konteks, 2) Komponen Input, 3) Komponen Proses, 4) Komponen Produk, kendala-kendala yang dijumpai selama pelaksanaan program. Data dikumpulkan dengan menggunakan beberapa metode diantaranya wawancara, studi dokumen, dan pemberian kuisioner. Data yang diperoleh selanjutnya dikonversi ke dalam skor Z, skor T, dan Tabel Kuadran Glickman. Data pokok dalam penelitian ini bersifat primer, karena langsung diperoleh melalui sumber (responden) melalui kuisioner. Data yang diperoleh berbentuk angka (kuantitatif) yaitu skor yang diperoleh responden setelah menjawab kuisioner. Adapun metode analisis data dalam penelitian ini melibatkan perhitungan skor Z, skor T, dan Tabel Kuadran Glickman sebagai berikut. Data yang diperoleh 
melalui kuisioner dalam penelitian ini terlebih dahulu ditransformasikan ke dalam skor baku atau skor standar yang terdiri dari skor $\mathrm{Z}$ dan skor $\mathrm{T}$ melalui persamaan sebagai berikut

$\mathrm{Z}=, \mathrm{T}=10 \mathrm{Z}+50(2)$

(Koyan, 2012a)

Sedangkan untuk mengetahui tingkat efektifitas dilakukan dengan analisis terhadap variabel context, input, process, dan product menggunakan analisis kuadran Glickman. Kualitas skor pada masingmasing variabel yaitu positif dan negatif yang dihitung menggunakan T skor. Jika T 50 maka kualitas skor tinggi atau positif $(+)$, sedangkan jika $\mathrm{T}<50$ maka kualitas skor rendah atau negatif.

\section{ANALISIS DAN PEMBAHASAN}

Evaluasi program ini dilakukan terhadap 123 orang responden yaitu kepala perpustakaan, pustakawan, dosen, dan mahasiswa STIKI Indonesia, dengan mengukur 1) komponen konteks yang meliputi visi misi perguruan tinggi, keberadaan sumber belajar, kurikulum, sarana pendukung kegiatan pendidikan, landasan hokum/kebijakan pendidikan yang berlaku, dan daya dukung masyarakat terhadap program, 2) komponen input meliputi pengadaan ruangan perpustakaan yang memadai, perabot perpustakaan, koleksi bahan pustaka, dan sumber dana, 3) komponen proses meliputi keterlaksanaan program perpustakaan kampus, proses pengadaan koleksi, proses tugas kepegawaian, dan proses administrasi, dan 4) komponen produk meliputi terwujudnya perpustakaan STIKI menjadi pusat kegiatan pembelajaran, terjadinya transfer atau alih informasi dari berbagai sumber di perpustakaan, kepuasan pengunjung terhadap kualitas layanan yang diberikan, dan terjadi peningkatan refleksi kunjungan.

Evaluasi pengelolaan perpustakaan STMIK STIKOM Indonesia adalah untuk menjawab permasalahan terkait efektivitas program yang sudah dan sedang berjalan dilihat dari masing-masing komponen, baik itu efektivitas komponen konteks, input, proses, maupun produk. Dengan menggunakan $\mathrm{T}$ skor, maka rekapitulasi skor masing-masing komponen disajikan sebagai berikut.

Tabel 1 Rekapitulasi Hasil Perhitungan Komponen Konteks Pengelolaan Perpustakaan STMIK STIKOM Indonesia

\begin{tabular}{llccll}
\hline \multirow{2}{*}{ No. } & \multirow{2}{*}{ Komponen Konteks } & \multicolumn{3}{l}{ Frekuensi } & \multirow{2}{*}{ Ket } \\
& & $\mathrm{f}+$ & $\mathrm{f}-$ & hasil & \\
\hline 1 & Kepala Perpustakaan & & 1 & - & Negatif \\
2 & Pustakawan & & 2 & - & Negatif \\
3 & Dosen & 10 & 10 & + & Positif \\
4 & Mahasiswa & 55 & 45 & + & Positif \\
Hasil & & 65 & 58 & + & Positif \\
\hline
\end{tabular}

Berdasarkan tabel di atas, dapat dijelaskan bahwa dari komponen konteks kepala perpustakaan menunjukkan nilai negatif, pustakawan menunjukkan nilai negatif, dosen menunjukkan nilai positif, dan mahasiswa menunjukkan nilai positif. Komponen kedua yaitu komponen input dapat disajikan dalam tabel sebagai berikut.

Tabel 2 Rekapitulasi Hasil Perhitungan Komponen Input Pengelolaan Perpustakaan STMIK STIKOM Indonesia

\begin{tabular}{cccccc}
\hline \multirow{2}{*}{ No. } & \multirow{2}{*}{ Komponen Konteks } & \multicolumn{3}{c}{ Frekuensi } & \multirow{2}{*}{ Ket } \\
\hline 1 & Kepala Perpustakaan & & 1 & - & Negatif \\
2 & Pustakawan & & 2 & - & Negatif \\
3 & Dosen & 15 & 5 & + & Positif \\
4 & Mahasiswa & 54 & 46 & + & Positif \\
& Hasil & 69 & 54 & + & Positif \\
\hline
\end{tabular}


Berdasarkan tabel, dapat dijelaskan bahwa dari komponnen konteks kepala perpustakaan menunjukkan nilai negatif, pustakawan menunjukkan nilai negatif, dosen menunjukkan nilai positif, dan mahasiswa menunjukkan nilai positif

\section{Tabel 3 Rekapitulasi Hasil Perhitungan Komponen Proses Pengelolaan Perpustakaan STMIK} STIKOM Indonesia

\begin{tabular}{llllll}
\hline \multirow{2}{*}{ No. } & \multirow{2}{*}{ Komponen Konteks } & \multicolumn{2}{c}{ Frekuensi } & \multirow{2}{*}{ Ket } \\
& & $\mathrm{f}+$ & $\mathrm{f}-$ & hasil & \\
\hline 1 & Kepala Perpustakaan & & 1 & - & negatif \\
2 & Pustakawan & 1 & 1 & & \\
3 & Dosen & 13 & 7 & + & positif \\
4 & Mahasiswa & 57 & 43 & + & positif \\
Hasil & & 71 & 52 & + & positif \\
\hline
\end{tabular}

Berdasarkan tabel di atas, dapat dijelaskan bahwa dari komponnen konteks kepala perpustakaan menunjukkan nilai negatif, pustakawan menunjukkan nilai positif dan negatif, dosen menunjukkan nilai positif, dan mahasiswa menunjukkan nilai positif.

Tabel 4 Rekapitulasi Hasil Perhitungan Komponen Produk Pengelolaan Perpustakaan STMIK STIKOM Indonesia

\begin{tabular}{llllll}
\hline \multirow{2}{*}{ No. } & \multirow{2}{*}{ Komponen Konteks } & \multicolumn{2}{l}{ Frekuensi } & \multirow{2}{*}{ Ket } \\
& & $\mathrm{f}+$ & $\mathrm{f}-$ & hasil & \\
\hline 1 & Kepala Perpustakaan & & 1 & - & Negative \\
2 & Pustakawan & 1 & 1 & & \\
3 & Dosen & 12 & 8 & + & Positif \\
4 & Mahasiswa & 65 & 35 & + & Positif \\
Hasil & & 65 & 58 & + & Positif \\
\hline
\end{tabular}

Berdasarkan tabel di atas, dapat dijelaskan bahwa dari komponnen konteks kepala perpustakaan menunjukkan nilai negatif, pustakawan menunjukkan nilai positif dan negatif, dosen menunjukkan nilai positif, dan mahasiswa menunjukkan nilai positif. Berdasarkan hasil masing-masing komponen yang dijelaskan di atas, maka secara keseluruhan data masing-masing komponen dapat disajikan dalam tabel berikut.

Tabel 5 Rekapitulasi Hasil Perhitungan Komponen Konteks, Input, Proses, dan Produk

\begin{tabular}{|c|c|c|c|c|c|}
\hline \multirow{2}{*}{ No. } & \multirow{2}{*}{ Komponen } & \multicolumn{3}{|c|}{ Frekuensi } & \multirow{2}{*}{ Keterangan } \\
\hline & & $\mathrm{f}+$ & f- & hasil & \\
\hline 1 & Konteks & 65 & 58 & + & Positif \\
\hline 2 & Input & 69 & 54 & + & Positif \\
\hline 3 & Proses & 71 & 52 & + & Positif \\
\hline 4 & Produk & 78 & 45 & + & Positif \\
\hline Hasil & & & & ++++ & Sangat efektif \\
\hline
\end{tabular}
menghasilkan + (efektif), untuk komponen input $\sum(+)>\sum(-)$ sehingga menghasilkan + (efektif), untuk komponen proses $\sum(+)>\sum(-)$ sehingga menghasilkan + (efektif), untuk komponen produk 
$\sum_{+}(+)>\sum(-)$ sehingga menghasilkan + (efektif). Jadi secara keseluruhan komponen menghasilkan ++

+. Berdasarkan Kuadran Glickman, diperoleh bahwa keseluruhan komponen berada di kuadran I dengan kategori sangat efektif.

Secara umum efektifitas pengelolaan perpustakaan STMIK STIKOM Indonesia terletak pada Kuadran I dalam Kuadran Glickman (++++), dimana hal tersebut berarti tergolong sangat efektif. Hasil ini didapat dikarenakan pada komponen Context, Input, Prosses dan Product secara keseluruhan menunjukkan angka positif. Hasil penelitian ini menunjukkan bahwa program pengelolaan perpustakaan STMIK STIKOM Indonesia secara umum telah mencapai sasaran secara maksimal sesuai misi perpustakaan tersebut, yaitu (1) menyediakan segala bentuk informasi yang sesuai dengan kurikulum yang berlaku di STMIK STIKOM Indonesia, (2) mengelola informasi agar bias diakses oleh pengguna dengan mudah, cepat, dan tepat, (3) memberikan fasilitas yang memadai kepada pemakai agar dapat mewujudkan fungsi perpustakaan sebagai sarana bantu proses belajar mengajar dan penelitian, (4) memberikan fasilitas ruang publik (public sphere) untuk masyarakat luas sebagai sarana pemberdayaan masyarakat, (5) menyebarkan informasi secara efektif dan efisien.

Ditinjau dari komponen konteks, secara lebih rinci, keefektifan pelaksanaan pengelolaan program perpustakaan di Perpustakaan STMIK STIKOM Indonesia ditunjukkan oleh hasil analisis data variabel konteks dengan perbandingan frekuensi positif dan frekuensi negatif sebesar 65 : 58. Ini berarti dari 123 responden terdapat 65 responden kategori positif dan 58 responden kategori negatif dengan besaran persentase sebesar $52,84 \%$ untuk kategori positif dan $47,16 \%$ untuk kategori negatif. Sebanyak 65 responden menyatakan bahwa misi dan tujuan perpustakaan, keberadaan sumber belajar, kurikulum, dan daya dukung masayarakat belajar sudah bagus. Oleh karena itu para stakeholder selayaknya mempertahankan dan meningkatkan pelaksanaan dan pemahaman terhadap komponen konteks melalui sumbangan pemikiran maupun material sehingga komponen konteks benar-benar terinternalisasi dengan pengelolaan perpustakaan.

Ditinjau dari komponen Input, berdasarkan hasil analisis data variabel masukan (input), terungkap bahwa perbandingan frekuensi positif dan frekuensi negatif sebesar 69:54. Ini berarti dari 123 responden terdapat 69 responden kategori positif dan 54 responden kategori negatif dengan besaran persentase sebesar 56,09\% untuk kategori positif dan 43,01\% untuk kategori negatif. Artinya, dalam pelaksanaan program pengelolaan perpustakaan STMIK STIKOM Indonesia telah memiliki struktur perpustakaan, gedung dan ruangan memadai sesuai kondisi riil, perabot, bahan koleksi, dan sumber dana untuk mendukung penyelenggaraan kegiatan program pengelolaan perpustakaan. Oleh karena itu diperlukan upaya untuk mempertahankan dan meningkatkan kondisi ditinjau dari komponen input agar perpustakaan STMIK STIKOM Indonesia tetap berfungsi secara berkesinambungan dan berkelanjutan.

Selanjutnya berdasarkan analisis data variabel proses ditemukan bahwa perbandingan frekuensi positif dan frekuensi negatif sebesar 71 : 52. Ini berarti dari 123 responden terdapat 71 responden kategori positif dan 52 responden kategori negatif dengan besaran persentase sebesar $57,72 \%$ untuk kategori positif dan 42,38\% untuk kategori negatif atau pengelolaan perpustakaan ditinjau dari komponen proses tergolong efektif. Hal ini berarti dalam pelaksanaan program pengelolaan perpustakaan STMIK STIKOM Indonesia telah melaksanakan proses pengeadaan koleksi, proses pengolahan koleksi, proses pemeliharaan koleksi, proses tugas kepegawaian, dan proses administrasi. Untuk mempertahankan dan meningkatkan komponen proses agar perpustakaan mampu memberikan layanan terbaiknya maka stakeholder perlu saling bersinergi mengatasi permasalahan-permasalahan yang masih muncul selama program berjalan.

Untuk analisis data variabel produk ditemukan bahwa perbandingan frekuensi positif dan frekuensi negatif sebesar $78: 45$. Ini berarti dari 123 responden terdapat 78 responden kategori positif dan 45 responden kategori negatif dengan besaran persentase sebesar $63,41 \%$ untuk kategori positif dan $36,59 \%$ untuk kategori negatif atau pengelolaan perpustakaan ditinjau dari komponen produk sudah tergolong efektif. Ini berarti pelaksanaan program pengelolaan perpustakaan STMIK STIKOM Indonesia sudah mencapai sasaran yang telah ditentukan yaitu terwujudnya perpustakaan perguruan tinggi menjadi pusat kegiatan belajar, terjadinya transfer atau alih informasi dari berbagai sumber di perpustakaan, terpenuhinya kualitas pengunjung terhadap kualitas layanan, serta terjadi peningkatan refleksi kunjungan.

Kondisi produk ini minimal harus dapat dipertahankan secara berkelanjutan dan berkesinambungan agar perpustakaan STMIK STIKOM Indonesia bias selalu konsisten dengan misi yang diembannya, salah satunya yaitu memberikan fasilitas yang memadai kepada pemustaka agar dapat mewujudkan fungsi perpustakaan sebagai sarana bantu proses belajar mengajar dan penelitian. 
Walaupun secara umum pengelolaan perpustakaan STMIK STIKOM Indonesia sudah termasuk kategori efektif, namun dari masing-masing komponen masih terdapat kendala yang ditunjukkan oleh respon negatif responden baik dalam komponen konteks, input, proses, maupun produk.

Walaupun secara umum pengelolaan perpustakaan STMIK STIKOM Indonesia sudah termasuk kategori efektif, namun dari masing-masing komponen masih terdapat kendala yang ditunjukkan oleh respon negatif responden baik dalam komponen konteks, input, proses, maupun produk.

Pada komponen konteks, hasil negatif masih ditunjukkan oleh kepala perpustakaan (1 orang) dan pustakawan ( 2 orang), dosen (10 orang), dan mahasiswa (45 orang). Hal ini disebabkan karena kepala perpustakaan dan pustakawan kurang dilibatkan dalam penyusunan visi dan misi perpustakaan sehingga hal-hal yang sifatnya teoritis terkait penyusunan visi dan misi perpustakaan sering terabaikan. Hal ini dapat berdampak pada kurangnya sosialiasi kepada warga belajar terkait komponen konteks ini. Hal yang dapat dilakukan diantaranya adalah dengan membangun sinergi yang baik dan melakukan pertemuanpertemuan secara rutin antara kepala perpustakaan, pustakawan, dosen, kepala STIKI, maupun warga belajar, sehingga upaya untuk memahami dan mengimplementasikan visi dan misi perpustakaan menjadi lebih terarah

\section{KESIMPULAN}

Berdasarkan analisis data dan temuan penelitian, maka dapat disimpulkan beberapa hal sebagai berikut, 1) Sesuai dengan kuadran Glickman, formula LMPH (CIPP) $=(++++)$ berada pada kuadran I. Dengan demikian berarti bahwa pelaksanaan pengelolaan program perpustakaan di STMIK STIKOM Indonesia berjalan dengan efektif, 2) Ditinjau dari komponen konteks persentase sebesar 52,84\% untuk kategori positif. Artinya, komponen konteks efektif dalam mendukung program pengelolaan perpustakaan di STMIK STIKOM Indonesia, 3) Ditinjau dari komponen Input, besaran persentase sebesar $56,09 \%$ untuk kategori positif. Artinya, komponen input efektif dalam mendukung program pengelolaan perpustakaan di STMIK STIKOM Indonesia, 4) Berdasarkan analisis data variabel proses, besaran persentase sebesar 57,72\% untuk kategori positif. Artinya, komponen proses efektif dalam mendukung program pengelolaan perpustakaan di STMIK STIKOM Indonesia, 5) Ditinjau dari komponen produk, besaran persentase sebesar $63,41 \%$ untuk kategori positif. Artinya, komponen produk efektif dalam mendukung program pengelolaan perpustakaan di STMIK STIKOM Indonesia.

Berdasarkan pembahasan dan simpulan penelitian bahwa pelaksanaan program efektivitas pengelolaan perpustakaan STMIK STIKOM Indonesia secara umum tergolong dalam kualifikasi efektif (CIPP $=++++$ ). Efektivitas pelaksanaan program tergantung pada kualitas fungsi konteks, input, proses, dan produk. Dengan demikian, temuan studi evaluative ini dapat dijadikan informasi yang positif bagi para pengembang pelaksanaan program atau pengampu kebijakan di lingkungan STMIK STIKOM Indonesia. Berdasarkan hal tersebut dapat direkomendasikan beberapa hal sebagai berikut, 1) Kepada instansi Yayasan Wahana Widya Wisesa Denpasar, hendaknya memberikan solusi bagi pengelolaan program khususnya komponen yang masih berjalan kurang efektif, dalam hal ini komponen input. Salah satunya dengan lebih meningkatkan monitoring dan evaluasi terhadap pelaksana program perpustakaan melalui tim khusus, agar perpustakaan benar-benar dapat berfungsi sebagai sumber belajar dan sumber informasi, menunjang kegiatan akademik, dan mampu memberikan layanan kepada warga belajar, 2) Bagi Ketua STMIK STIKOM Indonesia, untuk lebih memperhatikan hal-hal yang dapat menjadi kendala dalam pengelolaan perpustakaan khususnya komponen yang masih mendapatkan respon negatif, diantaranya meningkatkan komunikasi dan kolaborasi terhadap stakeholder terkait khususnya kepala perpustakaan dan pustakawan sebagai pengelola utama, lebih memperhatikan ide ataupun saran dari pihak terkait demi terwujudnya visi perpustakaan STMIK STIKOM Indonesia, 3) Bagi dosen, hendaknya selain menggunakan perpustakaan sebagai salah satu sumber belajar juga dapat membantu perpustakaan melalui sumbangansumbangan buku, penelitian, atau sejenisnya sehingga peran perpustakaan dapat dimaksimalkan dan memberikan kontribusi yang positif khususnya bagi lembaga/institusi, 4) Bagi mahasiswa, hendaknya menggunakan perpustakaan sebagai tempat belajar, tempat membaca, tempat rekreasi, demi untuk peningkatan kualitas diri dalam menghadapi tantangan masa depan di era globalisasi yang semakin kompetitif.

\section{DAFTAR PUSTAKA}

Arikunto. 2012. Dasar-dasar evaluasi pendidikan. Jakarta: Bumi Aksara

Candiasa. 2011a. Pengujian Instrumen Penelitian Disertai Aplikasi ITEMAN dan BIGSTEPS. Singaraja: Pascasarjana 
Dharma, Oka. 2013. Efektifitas Program Pengelolaan Perpustakaan di UPT Perpustakaan STMIK STIKOM Indonesia dengan Model CIPP. Prosiding. Seminar Nasional Riset Inovatif I. Singaraja: Universitas Pendidikan Ganesha

Koyan. 2012a. Statistik Pendidikan. Singaraja: STMIK STIKOM Indonesia Press

2012b. Evaluasi Program Pendidikan. Buku Ajar. STMIK STIKOM Indonesia: Pascasarjana

Marhaeni. 2012. Evaluasi Program Pendidikan. Buku ajar. STMIK STIKOM Indonesia: Pascasarjana

Mastaadhi. 2010. Studi evaluatif Program Pendidikan dan Pelatihan Penelitian Tindakan Kelas bagi Guru SD/MI dan SMP/MTs di Kabupaten Tabanan. Tesis (tidak diterbitkan). STMIK STIKOM Indonesia: Pascasarjana

Priantini. 2014. Pengaruh pemanfaatan perpustakaan STMIK STIKOM Indonesia Dalam menunjang prestasi belajar mahasiswa Pendidikan ekonomi universitas pendidikan ganesha Angkatan 2010-2012. Jurnal Volume 4 Nomor 1. Singaraja: STMIK STIKOM Indonesia

Stufflebeam, D. L. 2002. Evaluation Models. New York: Kluwer Academic

Undang-Undang Republik Indonesia Nomor 43 Tahun 2007

Undang-Undang Republik Indonesia Nomor 20 Tahun 2003. 